\title{
Wzmocniona współpraca w Unii Europejskiej po raz trzeci. Postępujące zróżnicowanie integracji oraz rozwój wzmocnionej wspólpracy i jej znaczenie dla funkcjonowania UE
}

\section{Wprowadzenic}

Na mocy Traktatu z Amsterdamu (TA) do prawa pierwotnego Unii Europejskiej (UE) wprowadzone zostały postanowienia dotyczące wzmocnionej współpracy. Stanowily one podstawę prawną zróżnicowania integracji, $\mathrm{z}$ istnieniem której de facto mieliśmy do czynienia od początku procesu integracji w ramach Wspólnot Europejskich (WE).

Przez ponad dziesięć lat regulacje prawne umożliwiające ustanowienie wzmocnionej współpracy nie były wykorzystywane. Jednak w roku 2010 Rada UE podjęła po raz pierwszy decyzję o upoważnieniu grupy państw UE do podjęcia wzmocnionej współpracy (w zakresie prawa właściwego dla rozwodów i separacji), a w roku 2011 - w sprawie jednolitego systemu patentowego (JSP) - po raz drugi. W ten sposób już w praktyce wzmocniona współpraca stała się jedną $\mathrm{z}$ form integracji w UE i bardzo istotnym czynnikiem wpływającym na zróżnicowanie integracji pomiędzy państwami członkowskimi Unii. Ponadto, do pogłębienia tego zróżnicowania bardzo mocno przyczynił się kryzys gospodarczy oraz podjęte przez państwa i instytucje UE działania mające na celu złagodzenie jego skutków i niedopuszczenie do powtórzenia się w przyszłości. Różnice pomiędzy państwami UE, których walutą jest euro, i nienależącymi do strefy euro, stały się jeszcze mocniej widoczne.

Faktem, który potwierdza rosnące znaczenie wzmocnionej współpracy dla funkcjonowania UE jest kolejna, podjęta w roku 2013, trzecia już decyzja Rady UE umożliwiająca jej ustanowienie - tym razem $\mathrm{w}$ dziedzinie podatku od transakcji finansowych (PTF). Co więcej, podejmowanie wzmocnionej współpracy nie obywa się bez kontrowersji i oporów tych państw, które w niej nie uczestniczą. Bowiem zarówno w przypadku jednolitego systemu patentowego, jak i podatku od transakcji finansowych, mieliśmy do czynienia z zaskarżaniem stosownych decyzji Rady UE do Trybunału Sprawiedliwości UE (TS UE). Biorąc pod uwagę te okoliczności, celem niniejszego artykułu jest przedstawienie rosnącego znaczenia wzmocnionej współpracy, w tym przede wszystkim kolejnej decyzji o jej ustanowieniu (w zakresie PTF), dla funkcjonowania UE. Dla pełniejszego zobrazowania kontekstu tego zagadnienia, syntetycznie wskazane zostaną także zawarte $w$ traktatach podstawy prawne wzmocnionej współpracy, przejawy zróżnicowania integracji sprzed roku 2010 (pierwsza decyzja Rady o ustanowieniu wzmocnionej współpracy), wymienione będą działania i decyzje podjęte przez pań- 
stwa i instytucje UE, w związku z kryzysem gospodarczym, które również wpłynęły na zróżnicowanie integracji w UE oraz krótko przybliżone zostaną dwa pierwsze przypadki ustanowienia wzmocnionej współpracy. Najistotniejsze wnioski zawarto w ostatniej części artykułu.

\section{Podstawy prawne wzmocnionej współpracy}

Jak wspomniano, postanowienia umożliwiające ustanowienie wzmocnionej współpracy zostały wprowadzone do prawa pierwotnego UE na mocy TA (Treaty of Amsterdam, 1997) i zawarte były w art. 43-45 Traktatu o Unii Europejskiej (TUE). Szczegółowe regulacje dotyczące możliwości podjęcia wzmocnionej współpracy w ramach byłego tzw. I filaru UE znajdowały się w art. 11 Traktatu ustanawiającego Wspólnotę Europejską (TWE), zaś w ramach byłego tzw. III filaru UE w art. 40 TUE. W byłym tzw. II filarze UE TA możliwości podjęcia wzmocnionej współpracy nie przewidywał. Pewną jej pośrednią formą było tylko tzw. konstruktywne wstrzymanie się od głosu, uregulowane $w$ art. 23 TUE.

Traktat z Nicei (Treaty of Nice, 2001) zawierał m.in. pewne szczegółowe zmiany dotyczące wzmocnionej współpracy, które zostały wprowadzone do wyżej wymienionych artykułów TUE i TWE. Ponadto wprowadzono możliwość ustanowienia wzmocnionej współpracy również w byłym tzw. II filarze UE - odpowiednie postanowienia zawarte zostaly $w$ art. $27 \mathrm{a}-27 \mathrm{e}$ TUE ${ }^{1}$.

Zgodnie z postanowieniami Traktatu z Lizbony (Traktat z Lizbony, 2007), regulacje dotyczące wzmocnionej współpracy zawarto zarówno w TUE (Wersja skonsolidowana Traktatu o Unii Europejskiej, 2010), jak i w Traktacie o funkcjonowaniu Unii Europejskiej (TFUE; Wersja skonsolidowana Traktatu o funkcjonowaniu, 2010). W TUE znajduje się tytuł IV „Postanowienia o wzmocnionej współpracy”, na który składa się tylko artykuł 20 i który stanowi bardzo ogólne ramy dla możliwości podjęcia wzmocnionej współpracy. Szczegółowe regulacje, stanowiące doprecyzowanie treści art. 20 TUE, zawarte zostały w Tytule III TFUE ,Wzmocniona współpraca” (art. 326-334). TL przewiduje także możliwość ustanowienia ,stałej współpracy strukturalnej” w obszarze wspólnej polityki bezpieczeństwa i obrony UE. Ogólne jej ramy reguluje art. 42 ust. 6 TUE, zaś postanowienia szczegółowe znajdują się w art. 46 TUE oraz w nowym, dołączonym do traktatów protokole (Protokól w sprawie, 2010).

Od postanowień zawartych w wymienionych artykułach, na mocy TL wprowadzono wyjątki dotyczące współpracy sądowej w sprawach karnych oraz współpracy policyjnej $w$ ramach unijnej przestrzeni wolności, bezpieczeństwa i sprawiedliwości. Zgodnie z TFUE, w przypadkach określonych w art. 82 ust. 2, art. 83 ust. 1, art. 86 ust. 1 oraz art. 87 ust. 2 procedura nawiązywania wzmocnionej współpracy jest nieco odmienna ${ }^{2}$.

\footnotetext{
Szczególowe przedstawienie postanowień regulujących wzmocnioną współpracę zawartych w Traktacie z Amsterdamu, Traktacie z Nicei oraz Traktacie ustanawiającym Konstytucję dla Europy oraz ich analiza: Kubin, 2006, s. 175-193.

2 Szerzej na temat wzmocnionej wspólpracy w Traktacie z Lizbony: Kubin, 2010, s. 119-135.
} 


\section{Zróżnicowanie integracji w UE (WE). Wzmocniona wspólpraca w zakresie prawa wlaściwego dla rozwodów i separacji oraz jednolitego systemu patentowego}

Z pewnymi przejawami zróżnicowania integracji w UE (a wcześniej we WE) mamy do czynienia od początku procesu integracji, a w miarę jego postępowania różnic tych przybywało. Wymieniając tylko w tym miejscu ${ }^{3}$ przejawy tego zróżnicowania można wskazać:

- ograniczone lub szczególne zastosowanie traktatów, na których opiera się funkcjonowanie UE, w odniesieniu do terytoriów zależnych państw członkowskich UE, obecnie wymienionych $w$ art. 355 TFUE. Taki stan rzeczy ma miejsce od traktatu ustanawiającego EWG (art. 227; Traktat ustanawiajqcy Europejska, 1957) pomimo, że zgodnie z art. 29 konwencji wiedeńskiej (Konwencja wiedeńska, 1969) umowy międzynarodowe wiążą państwa, które je zawarly, w odniesieniu do całego ich terytorium. Początkowo wyjątki te dotyczyły Algierii i francuskich departamentów zamorskich; później, wraz z kolejnymi rozszerzeniami WE (UE) o państwa posiadające terytoria w jakiś sposób od nich zależne, zamorskie czy wyspiarskie, liczba terytoriów objętych tego rodzaju wyjątkami wzrastała:

- prawo Belgii, Holandii i Luksemburga do tworzenia „związków regionalnych”, przewidziane już w TEWG (art. 233) i utrzymane do dziś (art. 350 TFUE po zmianach wprowadzonych na mocy TL). Oznacza ono w istocie możliwość głębszej integracji, czyli ustanowienia czegoś na kształt dzisiejszej wzmocnionej wspólpracy, ograniczonej tylko do tych trzech państw;

- tzw. okresy przejściowe, zawarte w kolejnych traktatach akcesyjnych, na podstawie których państwa przystępujące do WE (UE) w pełni dostosowują swoje prawodawstwo do acquis communautaire dopiero po jakimś czasie. Zdarzają się też sytuacje odwrotne, tzn. to „stare" państwa członkowskie dopiero po jakimś czasie w pełni postępują zgodnie z zasadami i treścią prawa UE (WE) - było tak np. w przypadku zawartej w traktacie akcesyjnym z 2003 r. możliwości otwarcia rynków pracy przez państwa UE dla obywateli państw przystępujących do UE w 2004 r. po kilkuletnim okresie przejściowym, co stanowiło odstępstwo od zasady swobody przepływu osób;

- porozumienia z Schengen z 1985 r. i 1990 r., dotyczące znoszenia kontroli na granicach wewnętrznych WE (UE) oraz wypracowany później w związku z nimi dorobek prawny, który do 1999 r. pozostawał poza ramami prawnymi $\mathrm{UE}^{4}$. Od początku jej powstania do tzw. strefy Schengen nie należały wszystkie państwa UE (WE), kolejne przystępowały do niej w różnym czasie i nie od razu były związane wszystkimi jej regulacjami prawnymi, do dziś nie należą do niej wszystkie państwa UE, natomiast jej członkami są także kraje spoza Unii;

- pozostawanie przez niektóre państwa UE poza strefą euro. Taka sytuacja była uwzględniona już w wtedy, gdy tworzono podstawy prawne Unii Gospodarczej

3 Szerzej na ten temat: Kubin, 2012, s. 74-78.

4 Dorobek Schengen zostal włączony w ramy prawne UE na podstawie protokołu dolączonego do TUE i TWE, który to protokól byl z kolei dolączony do Traktatu z Amsterdamu (Protocol integrating, 1997). 
i Walutowej (UGiW) - zgodnie z art. 109k TWE (Treaty on European, 1992) państwa członkowskie UE, które nie spełniają wszystkich kryteriów udziału w trzecim etapie UGiW, objęte są derogacją. Obecnie stanowi o tym art. 139 TFUE. Wielka Brytania i Dania uzyskały możliwość nieuczestniczenia w trzecim etapie UGiW na podstawie stosownych protokołów (Protocol on certain, 1992);

- prawo Danii do zachowania swojego prawodawstwa dotyczącego nabywania tzw. drugich domów (Protocol on the acquisition, 1992);

- możliwość Wielkiej Brytanii nieuczestniczenia w „Porozumieniu w sprawie polityki społecznej", zawartym pomiędzy pozostałymi jedenastoma ówczesnymi państwami członkowskimi UE i mającemu wprowadzić w życie postanowienia Karty Socjalnej z 1989 roku (Protocol on social, 1992);

- prawo przyznane Wielkiej Brytanii i Irlandii do wykonywania kontroli na granicach tych państw z innymi państwami UE (WE) bez względu na ówczesny art. 7a TWE (mówiący m.in. o swobodzie przepływu osób); analogiczne uprawnienia przyznano, na zasadzie wzajemności, innym państwom UE (WE), do których wjeżdżali ludzie $\mathrm{z}$ terytorium Wielkiej Brytanii i Irlandii (Protocol on the application, 1997);

- Wielka Brytania i Irlandia (Protocol on the position of the United Kingdom, 1997) oraz Dania (Protocol on the position of Denmark, 1997) nie były związane postanowieniami ówczesnego tytułu IIIa TWE (dotyczącego wiz, azylu, imigracji i innych polityk związanych ze swobodnym przepływem osób), chyba że państwa te wyraziłyby wolę udziału w przyjmowanych w ramach tych polityk środkach i działaniach;

- konwencja z Prüm (Konwencja pomiędzy, 2005), podpisana 27 maja 2005 r. przez siedem państw UE (Belgia, Niemcy, Hiszpania, Francja, Luksemburg, Holandia i Austria), dotycząca zintensyfikowania współpracy transgranicznej, zwłaszcza w zwalczaniu terroryzmu i przestępczości transgranicznej. Przyjęcie tej konwencji było przykładem pogłębiania integracji poza ramami prawnymi UE, podjętym już w czasie, gdy istniała możliwość podjęcia wzmocnionej współpracy. Kilka lat po jej przyjęciu, postanowienia konwencji z Prüm zostały włączone do dorobku prawnego UE (Decyzja Rady 2008/615/WSiSW i Decyzja Rady 2008/616/WSiSW) ${ }^{5}$;

- zgodnie z nowym protokołem dołączonym do traktatów stanowiących podstawę funkcjonowania UE na mocy TL, postanowienia zawarte w tytule IV (,Solidarność”; dotyczącego m.in. praw pracowników, zabezpieczenia społecznego i pomocy społecznej, ochrony zdrowia i ochrony środowiska) Karty Praw Podstawowych ,nie tworzą praw, które mogą być dochodzone na drodze sądowej” w Wielkiej Brytanii i Polsce, chyba że państwa te „przewidziały takie prawa w swoim prawie krajowym” (Protokól w sprawie stosowania, 2007);

- zgodnie ze zmienionymi na podstawie TL przywoływanymi wcześniej protokołami, Wielka Brytania i Irlandia nie muszą uczestniczyć we wnioskach lub inicjatywach formułowanych na podstawie dorobku Schengen a udział Danii w przyjmowaniu, wprowadzaniu w życie i rozwijaniu środków stanowiących rozwinięcie dorobku Schengen regulują postanowienia „Protokołu w sprawie stanowiska Danii” (Protokót w sprawie dorobku, 2007);

\footnotetext{
5 Szerzej na ten temat: Barcz, 2007.
} 
- Wielka Brytania i Irlandia (Protokót w sprawie stanowiska Zjednoczonego Królestwa, 2007), a także Dania (Protokót w sprawie stanowiska Danii, 2007) nie uczestniczą w przyjmowaniu środków objętych postanowieniami tytułu IV części trzeciej TFUE (dotyczącego przestrzeni wolności, bezpieczeństwa i sprawiedliwości).

Bardzo mocno na pogłębienie zróżnicowania integracji w UE wplynął także kryzys gospodarczy oraz podjęte w związku z nim przez państwa i instytucje UE działania i decyzje.

Głównym kryterium pogłębienia się tych zróżnicowań jest wskazane już wcześniej członkostwo w strefie euro.

Formalnym wyrazem pogłębienia politycznego i instytucjonalnego zróżnicowania w tej sferze jest dołączony do TL nowy „Protokół w sprawie eurogrupy” (Protokót w sprawie eurogrupy, 2007). Na jego podstawie sformalizowana została, funkcjonująca zgodnie z konkluzjami Rady Europejskiej z grudnia 1997 r., tzw. eurogrupa, stanowiąca nieformalne forum dyskusji ministrów finansów państwa strefy euro (Luxembourg European Council, 1997).

Przejawem utrwalania się zróżnicowania państw UE, którego kryterium jest członkostwo w unii walutowej, są szczyty szefów państw lub rządów państw strefy euro, odbywane przy okazji posiedzeń Rady Europejskiej. Na spotkaniu Rady Europejskiej 26 października 2011 r. m.in. postanowiono, że co najmniej dwa razy w roku (w miarę możliwości po spotkaniach Rady Europejskiej; w razie potrzeby mogą zostać zwołane dodatkowe spotkania) odbywać się będą szczyty państw strefy euro, w których uczestniczyć będą szefowie tych państw lub rządów i przewodniczący KE. Wyznaczany jest także przewodniczący szczytu państw strefy euro (Oświadczenie ze szczytu, 2011).

Następnym przejawem pogłębienia różnic pomiędzy państwami UE, w których walutą jest euro, a pozostałymi, jest tzw. „sześciopak”, który został przyjęty aby m.in. wzmocnić kontrolę polityk budżetowych państw UE, zapobiegać występowaniu nadmiernych deficytów budżetowych oraz zaostrzyć i przyspieszyć nakładanie sankcji za niewywiązywanie się z przyjętych zobowiązań. Dwa spośród tych aktów prawnych obowiązują tylko te państwa UE, w których walutą jest euro (rozporządzenia 1173/2011 i 1174/2011).

Kolejnym bardzo znaczącym dokumentem utrwalającym i pogłębiającym podział wśród państw UE jest „Traktat o stabilności, koordynacji i zarządzaniu w UGiW”, zwany potocznie „paktem fiskalnym” (Traktat o stabilności, 2012). Porozumienie co do jego zawarcia wypracowano na szczycie państw strefy euro 9 grudnia 2011 r. (Oświadczenie ze szczytu, 2011), zaś ostatecznie został podpisany na spotkaniu Rady Europejskiej 2 marca 2012 r. Uczynili to przedstawiciele wszystkich państw UE z wyjątkiem Wielkiej Brytanii i Czech. Traktat ten ma zastosowanie dla państw strefy euro (art. 1(2)) oraz dla tych państw, które go podpisały i ratyfikowały, które oświadczą, że chcą być wcześniej związane wszystkimi lub niektórymi postanowieniami tytułu III i IV traktatu (art. 14(5)).

Jeszcze innym dokumentem, którego znaczenie, po przyjęciu wspomnianego „sześciopaku” i ,paktu fiskalnego" jest relatywnie mniejsze, ale o którym należy wspom-

6 Na tzw. „sześciopk” składa się pięć rozporządzeń PE i Rady (1173/2011, 1174/2011, 1175/2011, 1176/2011, 1177/2011) oraz dyrektywa Rady 2011/85/UE. 
nieć, jest „Pakt euro plus” (pierwotnie nazywany „paktem na rzecz konkurencyjności”). Został on przyjęty na spotkaniu Rady Europejskiej 24-25 marca 2011 r. przez jeszcze inną niż miało to miejsce w przypadku wspomnianych wyżej dokumentów konfigurację państw UE - mianowicie przez państwa strefy euro oraz przez Polskę, Bułgarię, Danię, Litwę, Lotwę i Rumunię - i tym samym jest kolejnym przejawem postępującego zróżnicowania w UE (Pakt euro plus, 2011).

Na tym samym spotkaniu Rady Europejskiej (24-25 marca 2011 r.) podjęto także kilka decyzji, które pogłębiają i utrwalają różnice pomiędzy państwami strefy euro a pozostałymi członkami UE znacznie bardziej. Mianowicie Rada Europejska postanowiła (Podstawowe ustalenia, 2011) dodać do art. 136 TFUE ustęp, zgodnie z którym członkowie UGiW mogą ustanowić „,mechanizm stabilności”, w ramach którego możliwe będzie udzielenie pomocy finansowej. W związku z tą decyzją, Rada Europejska zdecydowała o utworzeniu przez państwa strefy euro stałego Europejskiego Mechanizmu Stabilności (EMS). Przejął on rolę stworzonych wcześniej mechanizmów pomocy państwom strefy euro o charakterze doraźnym - Europejskiego Instrumentu Stabilności Finansowej oraz Europejskiego Mechanizmu Stabilizacji Finansowej i ma dysponować środkami w wysokości 500 mld euro. To, co jest szczególnie ważne w kontekście problemu zróżnicowania integracji w UE, to przede wszystkim to, że mechanizm ten ma działać na potrzeby tylko państw strefy euro. Udział państw spoza strefy euro miałby polegać tylko na uczestniczeniu w pomocy państwom strefy euro.

Obok wskazanych różnic o charakterze formalnoprawnym, kryzys gospodarczy i jego następstwa, bardzo zróżnicowane w odniesieniu do poszczególnych państw UE, jeszcze bardziej uwidoczniły i pogłębiły różnice pomiędzy krajami UE pod względem znaczenia politycznego oraz wpływu na funkcjonowanie tej organizacji. Pisząc $w$ wielkim skrócie, bardzo wyraźnie osłabła pozycja polityczna państw, w które skutki kryzysu uderzyły najmocniej, których sytuacja gospodarcza pogorszyła się najbardziej i które zmuszone były zwrócić się o pomoc finansową, której warunki zostały formalnie określone i z których wywiązywanie się jest nadzorowane przez MFW, EBC i KE. $Z$ drugiej strony jeszcze bardziej wzrosła pozycja i znaczenie w UE Niemiec - państwo to i kanclerz Angela Merkel stała się „głównym rozgrywającym” w działaniach mających na celu walkę ze skutkami kryzysu i nieformalnym przywódcą państw $\mathrm{UE}^{7}$.

Jeśli natomiast chodzi o wzmocnioną współpracę, to po raz pierwszy Rada UE uznała, że spełnione zostały wszystkie przewidziane w TUE i TFUE warunki do tego, aby została ona ustanowiona i przyjęła odpowiednią decyzję, w roku 2010. Decyzja ta dotyczyła wzmocnionej współpracy w zakresie prawa właściwego dla rozwodów i separacji.

Na posiedzeniu Rady UE w dniach 5 i 6 czerwca 2008 r. przyjęto konkluzje (Council of the European Union, 2008), w których stwierdzono, że nie udało się osiagnąć jednomyślności wszystkich państw UE potrzebnej do dalszych prac nad zaproponowanym w lipcu 2006 r. przez Komisję rozporządzeniem (Komisja Europejska, 2006) zmieniającym rozporządzenie Rady (WE) nr 2201/2003 (Council Regulation 2201/2003) dotyczącym spraw małżeńskich. Rada stwierdziła także, że wystapiły w tej sprawie

7 Szerzej na ten temat zob.: Kubin, 2012, s. 81-88. 
trudności nie do pokonania, które uniemożliwiają osiągnięcie jednomyślności obecnie i w najbliższej przyszłości. Wyrażona została również opinia, zgodnie z którą cele proponowanego rozporządzenia nie mogą zostać osiagnięte w rozsądnym terminie - a więc zachodzą przesłanki określone w traktatach umożliwiające podjęcie wzmocnionej współpracy. W tej sytuacji Grecja, Hiszpania, Włochy, Luksemburg, Węgry, Austria, Rumunia i Słowenia wystąpiły 28 lipca 2008 r. z wnioskiem do KE wskazując, że mają zamiar ustanowić wzmocnioną współpracę w dziedzinie prawa właściwego dla spraw małżeńskich i zwróciły się do Komisji o przedłożenie odpowiedniego wniosku Radzie. 12 sierpnia 2008 r. taki sam wniosek skierowała do KE Bułgaria, do którego przyłączyły się Francja, Niemcy, Belgia, Łotwa, Malta oraz Portugalia. W związku z tym, że 3 marca 2010 r. Grecja wycofała swój wniosek, razem państw chcących ustanowienia wzmocnionej współpracy było czternaście. 16 czerwca 2010 r. zgodę na projekt decyzji Rady o ustanowieniu wzmocnionej współpracy wyraził Parlament Europejski (Parlament Europejski, 2010). Biorąc pod uwagę to, że wszystkie zawarte w TUE oraz TFUE konieczne warunki do ustanowienia wzmocnionej współpracy zostały spełnione, 12 lipca 2010 r. Rada podjęła decyzję upoważniającą ww. czternaście państw UE do ustanowienia między sobą wzmocnionej współpracy w dziedzinie prawa właściwego dla rozwodów i separacji (Decyzja Rady 2010/405/UE).

Ustanowienie wzmocnionej współpracy po raz drugi dotyczyło jednolitego systemu patentowego w UE. Prace nad takim systemem trwały od ponad 30 lat, a jego brak powodował, że działające na unijnym rynku przedsiębiorstwa musiały ponosić koszty ochrony patentów w każdym z państw UE osobno. KE wskazywała, że łączny koszt uzyskania ochrony patentowej w całej UE miał wynosić ponad 32 tys. euro, a jej uzyskanie jest złożone (Komisja Europejska, 2011). JSP ma pozwolić koszty te znacząco zredukować oraz zmniejszyć obciążenia związane $\mathrm{z}$ dopełnianiem niezbędnych formalności. Jak się jednak wskazuje, skutki dla poszczególnych, bardzo przecież zróżnicowanych pod względem poziomu rozwoju technologicznego, państw UE zaangażowanych w to przedsięwzięcie oraz dla przedsiębiorstw mogą być bardzo różne, w tym również negatywne?

Decyzja umożliwiająca podjęcie wzmocnionej współpracy została podjęta zgodnie z art. 329 ust. 1 TFUE przez Radę UE 10 marca 2011 r. (Decyzja Rady 2011/167/UE). $\mathrm{Na}$ jej podstawie we wzmocnionej współpracy dotyczącej jednolitego systemu ochrony patentowej uczestniczą wszystkie państwa UE z wyjątkiem Włoch i Hiszpanii. KE przedstawiła propozycję dotyczącą przyjęcia odpowiednich rozporządzeń 13 kwietnia 2011 r. (Komisja Europejska, 2011). W skład pakietu tworzącego JSP wchodzą dwa rozporządzenia: dotyczące jednolitego systemu ochrony patentowej (Rozporządzenie 1257/2012), związanych z nim odpowiednich regulacji językowych (Rozporządzenie 1260/2012) i umowa międzynarodowa, na mocy której ma powstać Jednolity Sąd Patentowy, przed którym rozstrzygane byłyby spory (Porozumienie, 2013).

8 Szerzej na ten temat np.: Peers, 2010, s. 339-358; Kuipers, 2012, s. 201-229; Fiorini, 2010, s. $1143-1158$.

9 Zob. np. dyskusję na ten temat oraz stanowiska w tej sprawie instytucji, organizacji, grup interesu, ekspertów itp. na stronie internetowej Polskiej Izby Rzeczników Patentowych. 
Jak zasygnalizowano we wstępie, działania mające na celu ustanowienie wzmocnionej współpracy w zakresie JSP spotkały się ze sprzeciwem nieuczestniczących w niej państw, czyli Hiszpanii i Włoch. Państwa te zaskarżyły decyzję Rady do TS UE. Na poparcie swojej skargi Hiszpania podnosiła głównie, że zaskarżona decyzja ,jest dotknięta wadą nadużycia władzy i narusza system sądowniczy Unii”, a także, że naruszone zostały wymogi ustanowienia wzmocnionej współpracy określone w art. 20 TUE oraz art. 326 i 327 TFUE (pkt 7 wyroku). Włochy natomiast podnosiły brak kompetencji Rady do ustanowienia wzmocnionej współpracy w sprawie JSP oraz „nadużycie władzy i naruszenie istotnych wymogów proceduralnych" (pkt 8). W swoim wyroku z 16 kwietnia 2013 r. TS wszystkie argumenty Hiszpanii i Włoch uznał za bezzasadne i w związku z tym oddalił skargi tych państw (Sprawy połączone C-274/11 iC-295/11).

\section{Ustanowienie wzmocnionej wspólpracy państw UE w sprawie systemu podatku od transakcji finansowych}

Po raz trzeci wzmocniona współpraca w UE została ustanowiona w dziedzinie podatku od transakcji finansowych. Warto w tym miejscu wspomnieć, że idea wprowadzenia tego rodzaju podatku liczy kilkadziesiąt lat, a zaproponowana została przez Jamesa Tobina w 1972 r. w warunkach rozpadu międzynarodowego systemu walutowego z Bretton Woods - po raz pierwszy o propozycji tej J. Tobin pisał w 1974 r. (Tobin, 1974), a później w 1978 r. Proponował on wprowadzenie „międzynarodowego, zunifikowanego podatku od wszystkich transakcji wymiany jednej waluty na inną, proporcjonalnego do wielkości tych transakcji" (Tobin, 1978, s. 155).

W przypadku UE, działania mające na celu wprowadzenie PTF związane są z kryzysem gospodarczym. Jak w jednym $z$ dokumentów dotyczących PTF pisze KE, „do kryzysu gospodarczego w znacznej mierze przyczynił się sektor finansowy, natomiast koszty tego kryzysu ponieśli ogólnie obywatele Europy i rządy. W Europie i na arenie międzynarodowej istnieje całkowita zgodność co do tego, że sektor finansowy powinien wykazywać większe zaangażowanie, biorąc pod uwagę koszty przezwyciężania kryzysu i obecne zaniżone opodatkowanie tego sektora" (Komisja Europejska, 2013).

Wniosek dotyczący dyrektywy Rady w sprawie wspólnego systemu podatku od transakcji finansowych Komisja Europejska przyjęła 28 września 2011 r. (European Commission, 2011). W kontekście tematu niniejszego opracowania istotne jest to, że podstawą prawną proponowanej przez KE dyrektywy był artykuł 113 TFUE, a więc do jej przyjęcia konieczna jest jednomyślność Rady UE, stanowiącej po konsultacji z Parlamentem Europejskim i Komitetem Ekonomiczno-Społecznym (KE-S).

Parlament Europejski 23 maja 2012 r. wydał pozytywną opinię o wniosku KE i zaproponował do niego poprawki (Parlament Europejski, 2012a). Pozytywną opinię ws. wniosku wydał także KE-S (Komitet Ekonomiczno-Społeczny, 2012) oraz Komitet Regionów (Komitet Regionów, 2012).

Treść wniosku KE była przedmiotem posiedzeń Rady UE od listopada 2011 r. do lipca 2012 r. M.in. na posiedzeniu 22 czerwca 2012 r. potwierdzono, że nie uda się osiagnąć koniecznej jednomyślności dla PTF w formie zaproponowanej przez KE w przewidywalnej przyszłości (Rada UE, 2012). Także w konkluzjach ze spotkania 
Rady Europejskiej 28-29 czerwca 2012 r. stwierdzono, że ,jak odnotowano na posiedzeniu Rady 22 czerwca 2012 r., nie zostanie przyjęty w rozsądnym terminie wniosek w sprawie podatku od transakcji finansowych. W związku z tym kilka państw członkowskich zgłosi wniosek o wzmocnioną współpracę w tym obszarze [...]" (Rada Europejska, 2012, s. 13). W ten sposób, warunek określony w art. 20 ust. 2 TUE, zgodnie z którym wzmocniona współpraca może być ustanowiona wyłącznie w ostateczności, został spełniony.

W konsekwencji, pomiędzy 28 września a 23 października 2012 r. jedenaście państw członkowskich UE (Belgia, Niemcy, Estonia, Grecja, Hiszpania, Francja, Włochy, Austria, Portugalia, Słowenia i Słowacja) poinformowało KE o tym, że zamierzają ustanowić między sobą wzmocnioną współpracę w sprawie podatku od transakcji finansowych. Odpowiedni wniosek KE przedłożyła Radzie 25 października 2012 r. (European Commission, 2012). Stosownie do art. 329 ust. 1 TFUE, 12 grudnia 2012 r. zgodę na wniosek dotyczący decyzji Rady, bez przesądzania o uczestnictwie poszczególnych państw członkowskich, wyraził PE (Parlament Europejski, 2012b).

Rada UE przyjęła decyzję upoważniającą do podjęcia wzmocnionej współpracy w dziedzinie PTF 22 stycznia 2013 r. (Decyzja Rady 2013/52/UE). W decyzji tej stwierdzono, że także inne (obok wspomnianego wynikającego z art. 20 ust. 2 TUE) określone w przywołanych wcześniej postanowieniach TUE i TFUE warunki ustanowienia wzmocnionej współpracy zostały spełnione. Zgodnie z art. 1 tej decyzji, upoważnia ona ww. jedenaście państw do podjęcia między sobą wzmocnionej współpracy dla celów ustanowienia wspólnego systemu PTF. Następstwem tej decyzji było przyjęcie 14 lutego 2013 r. przez KE wniosku dotyczącego dyrektywy Rady w sprawie wdrożenia wzmocnionej współpracy w dziedzinie PTF (Komisja Europejska, 2013). Oparty on był na wniosku KE z 2011 r.; zawierał kilka zmian m.in. wynikających z faktu ustanowienia wzmocnionej współpracy.

Podobnie jak to miało miejsce w przypadku JSP, decyzja Rady upoważniająca do ustanowienia wzmocnionej współpracy w dziedzinie PTF została zaskarżona do TS UE. 18 kwietnia 2013 r. W. Brytania, na podstawie art. 263 TFUE, wniosła skargę o stwierdzenie nieważności decyzji Rady 2013/52/UE w związku z naruszeniem art. 327 TFUE i art. 332 TFUE oraz międzynarodowego prawa zwyczajowego (Sprawa C-209/13).

Na poparcie swojej skargi W. Brytania podnosiła dwa zarzuty. Pierwszy dotyczył naruszenia art. 327 TFUE i międzynarodowego prawa zwyczajowego, w zakresie, w jakim zaskarżona decyzja upoważnia do przyjęcia PTF wywołującego skutki pozaterytorialne.

Biorąc pod uwagę treść wniosku KE z 2011 r., zdaniem W. Brytanii decyzja Rady umożliwia ustanowienie PTF mającego zastosowanie do podmiotów, osób lub operacji na terytorium nieuczestniczących państw członkowskich, co naruszałoby kompetencje i prawa owych państw (pkt 18 i 19). Ponadto, zdaniem W. Brytanii międzynarodowe prawo zwyczajowe dopuszcza, aby przepisy miały skutek pozaterytorialny, tylko wtedy, ,gdy pomiędzy okolicznościami faktycznymi lub podmiotami a państwem wykonującym w tym względzie swą kompetencję istnieje wystarczająco ścisły związek, by uzasadnić ingerencję w suwerenne kompetencje innego państwa" (pkt 20). Tymczasem wedle W. Brytanii w przedmiotowej sprawie, skutki pozaterytorialne przyszłego PTF wynikające $\mathrm{z}$,zasady wzajemności” i ,zasady miejsca emisji” „nie są uzasadnione 
żadną regułą z zakresu kompetencji podatkowych dopuszczoną w prawie międzynarodowym" (pkt 21).

Drugi zarzut W. Brytanii dotyczyl naruszenia art. 332 TFUE w zakresie, w jakim decyzja 2013/52/UE upoważnia do przyjęcia PTF nakładającego koszty na państwa członkowskie, które nie uczestniczą we wzmocnionej współpracy. Zgodnie z art. 332 TFUE koszty związane z wykonaniem wzmocnionej współpracy w zakresie PTF mogą obciążać tylko uczestniczące we wzmocnionej współpracy państwa UE. Tymczasem według W. Brytanii realizacja wzmocnionej współpracy w zakresie PTF będzie prowadzić do powstania kosztów również po stronie nieuczestniczących państw członkowskich, w związku z zastosowaniem dyrektywy Rady 2010/24/UE z dnia 16 marca 2010 r. w sprawie wzajemnej pomocy przy odzyskiwaniu wierzytelności dotyczących podatków, ceł i innych obciążeń oraz dyrektywy Rady 2011/16/UE z dnia 15 lutego 2011 r. w sprawie współpracy administracyjnej w dziedzinie opodatkowania i uchylającej dyrektywę 77/799/EWG (pkt 22). Jak wskazywała W. Brytania, te dwie dyrektywy nie upoważniają nieuczestniczących państw członkowskich do dochodzenia zwrotu kosztów wzajemnej pomocy i współpracy administracyjnej związanych z zastosowaniem owych dyrektyw do przyszłego PTF (pkt 23).

Zdaniem drugiej strony sporu, czyli Rady UE, zarzuty te są nieuzasadnione. Bowiem zakwestionowane przez W. Brytanię zasady opodatkowania „stanowią w obecnym stadium okoliczności czysto hipotetyczne, odnoszące się do przepisów, które dopiero zostaną ustanowione". W konsekwencji argumenty W. Brytanii ,oparte na podniesionych skutkach pozaterytorialnych przyszłego PTF, są przedwczesne i maja charakter spekulacji” (pkt 26).

Natomiast w odniesieniu do drugiego zarzutu W. Brytanii, to ,prowadzi on do przedwczesnej debaty dotyczącej sposobu, w jakim prawodawca Unii ureguluje kwestię poniesienia kosztów związanych z wykonaniem wzmocnionej współpracy, do której upoważniła zaskarżona decyzja. Ponadto owa decyzja nie reguluje w żaden sposób kwestii wzajemnej współpracy dla celów zastosowania przyszłego PTF" (pkt 27). Poza tym, zdaniem Rady (oraz popierajacej ją Austrii, Portugalii i KE) drugi zarzut skargi W. Brytanii jest oparty na błędnej interpretacji art. 332 TFUE. Bowiem artykuł ten dotyczy ,jedynie wydatków operacyjnych obciążających budżet Unii w związku z aktami ustanawiającymi wzmocnioną współpracę, a nie wydatków zakwestionowanych przez Zjednoczone Królestwo, które mogą zostać poniesione przez państwa członkowskie na podstawie dyrektyw 2010/24 i 2011/16" (pkt 28).

W swoim wyroku TS UE odrzucił obydwa zarzuty podnoszone przez W. Brytanie i oddalił skargę tego państwa (pkt 40). Jeśli chodzi o pierwszy zarzut, to TS UE orzekł, że ,zasady opodatkowania zakwestionowane przez Zjednoczone Królestwo nie stanowią w żadnym razie części owej decyzji" (pkt 36). Natomiast w odniesieniu do drugiego zarzutu TS UE stwierdził, że ,zaskarżona decyzja nie zawiera żadnego przepisu dotyczącego kwestii wydatków związanych z wykonaniem wzmocnionej współpracy, do której upoważnia” (pkt 37). Ponadto, „kwestia ewentualnego wpływu przyszłego PTF na koszty administracyjne nieuczestniczących państw członkowskich nie może być badana, dopóki zasady opodatkowania owym podatkiem nie zostaną ostatecznie ustanowione w ramach wykonania wzmocnionej współpracy, której dotyczy upoważnienie udzielone w zaskarżonej decyzji" (pkt 38). 
Zgodnie z TFUE i zarysowaną wcześniej procedurą, na temat wniosku KE z lutego 2013 r. swoją opinię wydał PE - 3 lipca 2013 r. zatwierdził po poprawkach wniosek Komisji (Parlament Europejski, 2013). Obecnie (czerwiec 2015 r.) wniosek dotyczący dyrektywy Rady w sprawie wdrożenia wzmocnionej współpracy w dziedzinie podatku od transakcji finansowych jest przedmiotem debaty w Radzie UE oraz jej organach przygotowawczych. W przyjętym 6 maja 2014 r. oświadczeniu ministrowie 10 państw biorących udział we wzmocnionej współpracy (z wyjątkiem Słowenii) wyrazili chęć stopniowego wprowadzania PTF, który w pierwszej kolejności miałby objąć „instrumenty udziałowe i niektóre instrumenty pochodne" (Rada UE, 2014).

\section{Podsumowanie i wnioski. Znaczenie ustanowienia wzmocnionej wspólpracy w dziedzinie systemu podatku od transakcji finansowych dla rozwoju i funkcjonowania UE}

Wydaje się, że jeśli chodzi o skutki ustanowienia wzmocnionej współpracy w dziedzinie podatku od transakcji finansowych, to można wyróżnić dwie ich grupy. Pierwsza to ta, z której wynikają następstwa tej decyzji w „węższym” sensie, tzn. odnoszące się stricte do tej sfery, której decyzja ta dotyczy. Chodzi tutaj m.in. o konsekwencje wprowadzenia PTF dla różnego rodzaju podmiotów działających na rynkach finansowych (banki, fundusze inwestycyjne, fundusze emerytalne, firmy ubezpieczeniowe i reasekuracyjne, giełdy papierów wartościowych itp.), wpływ na stabilność sektora finansowego, wpływ na koszt pozyskania kapitału dla podmiotów, które uzyskują go na rynkach finansowych, zapewnienie określonych dochodów z tytułu wprowadzonego podatku itp. Warto w tym kontekście wskazać, że w decyzji Rady 2013/52/UE upoważniającej do podjęcia wzmocnionej współpracy w zakresie PTF wskazuje się następujące cele takiego podatku:

- uczestnictwo sektora finansowego „W należny i znaczący sposób w ponoszeniu kosztów kryzysu";

- „sprawiedliwe względem innych sektorów” opodatkowanie sektora finansowego;

- zniechęcenie do „podejmowania nadmiernie ryzykownych działań przez instytucje finansowe";

- „uzupełnienie środków regulacyjnych mających na celu uniknięcie przyszłych kryzysów";

- „wygenerowanie dodatkowych dochodów dla budżetów ogólnych lub konkretnych celów politycznych" (Decyzja Rady 2013/52/UE).

Według szacunków KE, ustanowienie wzmocnionej współpracy w dziedzinie PTF przez 11 państw UE mogłoby przynieść 31 mld euro wpływów (Komisja Europejska, 2013, s. 16).

Pytanie, jakie w związku z wprowadzeniem PTF się w tym miejscu nasuwa, to przede wszystkim to, czy podatek taki okaże się skuteczny, tzn. czy pozwoli osiągnąć ww. cele? Chodzi tutaj przede wszystkim o to, czy rezultatem wprowadzenia PTF tylko w niektórych państwach UE nie będzie swego rodzaju ,ucieczka" objętych nim transakcji poza system, tzn. do państw UE nieuczestniczących we wzmocnionej współpracy, a przede wszystkim poza UE - tak, aby podatku tego uniknąć? Jak wspomniano 
wcześniej, sama idea opodatkowania transakcji finansowych liczy kilkadziesiąt lat, ale jeden $\mathrm{z}$ głównych problemów związanych z jej realizacją polega na tym, że aby podatek taki był naprawdę efektywny, system musi być odpowiednio „szczelny”, tzn. podatek musi być skonstruowany tak, aby niemożliwe albo bardzo trudne było jego uniknięcie. Funkcjonowanie wszelkiego rodzaju tzw. „rajów podatkowych” skuteczność takiego podatku osłabia albo wręcz eliminuje. Należy tutaj zwrócić uwage, że przyjęte przez KE przy konstruowaniu projektu dyrektywy zasady miejsca siedziby i emisji mają ograniczyć możliwości ,ucieczki” przed proponowanym opodatkowaniem. Inny problem w kontekście skuteczności PTF to taki, czy wzrost kosztów angażowania się przez sektor finansowy w pewnego rodzaju ryzykowne transakcje finansowe rzeczywiście przyczyni się do ich ograniczenia? Wydaje się, że dziś pełna i pewna odpowiedź na tego rodzaju pytania nie jest możliwa - będzie to możliwe dopiero po pewnym czasie funkcjonowania tego podatku. Jak się wskazuje (Grahl, Lysandrou, 2014, s. 248), jeśli celem propozycji KE wprowadzenia PTF było nie tylko to, aby instytucje finansowe poniosły część kosztów kryzysu finansowego, ale także spowodowanie zmian w ich działaniu tak, aby zapobiec wystapieniu kryzysu w przyszłości, to lepszym rozwiązaniem byłoby wprowadzenie nie PTF, ale podatku od działalności finansowej (ang. financial activities tax).

Druga grupa następstw ustanowienia wzmocnionej współpracy w dziedzinie podatku od transakcji finansowych dotyczy jej znaczenia „szerszego”, tzn. dotyczącego dalszego rozwoju i funkcjonowania UE. W tym szerszym aspekcie można wskazać na kilka aspektów.

Po pierwsze, decyzja Rady UE upoważniająca do ustanowienia wzmocnionej współpracy w dziedzinie PTF jest już trzecią decyzją o podjęciu wzmocnionej współpracy.

Najpierw, przez ponad dekadę, postanowienia o wzmocnionej współpracy nie były wykorzystywane. Trzykrotne ustanowienie wzmocnionej współpracy od roku 2010 oznacza, że wzmocniona współpraca staje się stałym elementem funkcjonowania UE. Zatem cel, jaki przyświecał wprowadzeniu do prawa UE możliwości ustanowienia wzmocnionej współpracy, czyli zabezpieczenie procesu integracji przed jego stagnacją w warunkach coraz większej liczby państw członkowskich (Kubin, 2010, s. 131), co siłą rzeczy stanowi utrudnienie dla pogłębiania integracji (i już samo w sobie przyczynia się do pogłębienia zróżnicowania wewnątrz UE), wraz z kolejnymi decyzjami o wzmocnionej współpracy jest osiagany. Jan Barcz pisał, że zwiększenie elastyczności w UE jest rzeczą, ,naturalną” i ma pozwalać na „uwzględnianie specyfiki poszczególnych państw”' UE oraz ,zapobiegać budowaniu 'na zewnątrz' Unii form współpracy grupowej” (Barcz, 2008, s. 85), natomiast Danuta Hübner stwierdziła, że ,to, co nazywa się [...] wzmocnioną współpracą jest ważnym elementem stymulującym integrację. Napędza jej rozwój" (Hübner, 2003). Co więcej, kwestie, w których wzmocniona współpraca została ustanowiona - przede wszystkim jednolity system patentowy i podatek od transakcji finansowych - nie mają charakteru marginalnego, ale bez wattpienia należą do bardzo istotnych, dotykających bardzo wiele podmiotów, mających znaczący wpływ na ich sytuację na wspólnym rynku i z tego powodu mogących skutkować sprzecznościami interesów i konfliktami.

Po drugie, trzecia decyzja o wzmocnionej współpracy oznacza dalsze pogłębianie się zróżnicowania integracji w UE, które, jak to zostało wskazane, i bez takiej formy 
współpracy było znaczące. Nasuwa to pytania np. o spoistość UE czy przyszłość współpracy jej państw członkowskich. Jednakże trzykrotne ustanowienie wzmocnionej współpracy, za każdym razem z różną konfiguracją państw w niej uczestniczących, nie pozwala jeszcze wysnuwać wniosków co do jakiegoś trwalszego wykształcenia się w UE swoistej ,awangardy” integracji, czyli grupy państw, które uczestniczą w każdym przedsięwzięciu mającym na celu pogłębienia integracji. Najważniejszym kryterium zróżnicowania integracji w UE nadal pozostaje członkostwo w strefie euro.

Po trzecie, trzykrotne ustanowienie wzmocnionej współpracy powoduje, że coraz aktualniejsze stają się kwestie o charakterze prawno-politycznym, dotyczącym zgodności wzmocnionej współpracy $\mathrm{z}$ takimi podstawowymi zasadami integracji w ramach UE i unijnego prawa jak zasada solidarności, równości państw członkowskich oraz jedności norm prawa UE. Chodzi o to, że wzmocniona współpraca wprowadza „odstępstwa od zasady równości państw członkowskich" wobec prawa UE, ,prowadzi bowiem do nieuzasadnionego zróżnicowania praw i obowiązków państw członkowskich w zależności od tego czy i ewentualnie w ilu kręgach współpracy uczestniczą" (Dudziak, 2003, s. 37-38). Częste stosowanie wzmocnionej współpracy „skutkować będzie również postępującą fragmentaryzacją systemu prawnego" UE „oraz jego indywidualizacją" i ,postępującą erozją zasady jedności porządku wspólnotowego" (Dudziak, 2003, s. 37-38).

Po czwarte, należy zwrócić uwagę na to, że dwukrotnie decyzje o wzmocnionej współpracy zostały zaskarżone do TS UE przez państwa w tej współpracy nieuczestniczące. Taki stan rzeczy, a więc wyraźne wykształcenie się dwóch stron i zaistnienie pomiędzy nimi sporu raczej trudno uznać za czynnik pozytywnie wpływający na stosunki pomiędzy państwami członkowskimi UE. Z jednej więc strony, wzmocniona współpraca może stać się bardzo znaczącą przyczyną konfliktów w UE. Z drugiej strony, czynnikiem, który powoduje, że raczej można wykluczyć powstanie jakichś trwałych podziałów pomiędzy państwami UE, i który będzie ewentualne konflikty łagodził jest to, że nawet w przypadku podejmowania kolejnych decyzji o wzmocnionej współpracy i zaskarżania ich do TS UE przez państwa nieuczestniczące w tej wspólpracy, najprawdopodobniej w prawie każdym przypadku grupy państw uczestniczących we wzmocnionej współpracy i jej przeciwne będą różne - tak, jak miało to miejsce w trzech dotychczasowych przypadkach. Tak, jak ma to miejsce w wielu innych aspektach funkcjonowania UE, dzisiejsi sojusznicy jutro mogą stać się oponentami, co nie przeszkodzi im pojutrze ponownie wspólpracować.

Po piąte, wskazana wyżej zmienność, jeśli chodzi o udział i stosunek do wzmocnionej współpracy państw UE, musi być opatrzona bardzo istotnym zastrzeżeniem. Chodzi o to, że państwem, które w wyniku decyzji o wzmocnionej współpracy w dziedzinie PTF po raz kolejny znalazło się poza grupą państw mających na celu pogłębienie integracji, jest W. Brytania. Biorąc pod uwage wskazane przejawy zróżnicowania integracji istniejące jeszcze przed ustanowieniem wzmocnionej współpracy po raz pierwszy, kraj ten w największym stopniu korzysta z możliwości nieuczestniczenia w różnego rodzaju wspólnych przedsięwzięciach państw UE. W sytuacji zapowiedzianego przez premiera W. Brytanii Davida Camerona referendum dotyczaceego dalszego członkostwa tego państwa w UE, wzmocniona współpraca w dziedzinie tak istotnej i „wrażliwej” jak opodatkowanie transakcji finansowych oraz przegrana 
sprawa przed TS UE mogą być czynnikiem bardzo znaczącym w kontekście przyszłości W. Brytanii w UE.

\section{Bibliografia}

Barcz J. (2007), Wlaczenie postanowień konwencji z Prüm do prawa UE, „Europejski Przegląd Sądowy" nr 5.

Barcz J. (2008), Zasadnicze reformy strukturalne ustroju Unii Europejskiej, w: Traktat z Lizbony. Glówne reformy ustrojowe Unii Europejskiej, red. J. Barcz, Urząd Komitetu Integracji Europejskiej, Warszawa.

Council of the European Union (2003), Proposal for a Council Regulation amending Regulation (EC) 2201/2003 as regards jurisdiction and introducing rules concerning applicable law in matrimonial matters (Rome III) - Political guidelines, 9985/08 JUSTCIV 111, http://euzpr.eu/eu-

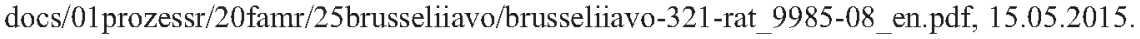

Council Regulation (EC) No 2201/2003 of 27 November 2003 concerning jurisdiction and the recognition and enforcement of judgments in matrimonial matters and the matters of parental responsibility, repealing Regulation (EC) No 1347/2000, O.J., L 338, 23.12.2003.

Decyzja Rady 2008/615/WSiSW z dnia 23 czerwca 2008 r. w sprawie intensyfikacji wspótpracy transgranicznej, szczególnie w zwalczaniu terroryzmu i przestepczości transgranicznej, Dz. Urz., L 210, 6.08.2008.

Decyzja Rady 2008/616/WSiSW z dnia 23 czerwca 2008 r. w sprawie wdrożenia decyzji 2008/616/WSiSW w sprawie intensyfikacji wspólpracy transgranicznej, szczególnie w zwalczaniu terroryzmu i przestępczości transgranicznej, Dz. Urz., L 210, 6.08.2008.

Decyzja Rady z dnia 12 lipca 2010 r. w sprawie upoważnienia do podjęcia wzmocnionej wspótpracy w dziedzinie prawa wlaściwego dla rozwodów i separacji (2010/405/UE), Dz. Urz., L 189, 22.07.2010.

Decyzja Rady z dnia 10 marca 2011 r. w sprawie upoważnienia do podjęcia wzmocnionej wspótpracy $w$ dziedzinie tworzenia jednolitego systemu ochrony patentowej (2011/167/UE), Dz.Urz., L 76, 22.03.2011.

Dyrektywa Rady 2011/85/UE z dnia 8 listopada 2011 r. w sprawie wymogów dla ram budżetowych państw czlonkowskich, Dz. Urz. UE, L 306, 23.11.2011.

Decyzja Rady z dnia 22 stycznia 2013 r. upoważniajaca do podjęcia wzmocnionej wspólpracy w dziedzinie podatku od transakcji finansowych (2013/52/UE), Dz. Urz. UE, L 22, 25.01.2013.

Dudziak S. (2003), Mechanizm wzmocnionej wspólpracy na tle konstytucyjnych zasad porzqdku prawnego Unii Europejskiej, „Kwartalnik Prawa Publicznego”, nr 1.

European Commission (2006), Proposal for a Council Regulation amending Regulation (EC) $2201 / 2003$ as regards jurisdiction and introducing rules concerning applicable law in matrimonial matters, COM(2006) 399 final, http://eurlex.europa.eu/LexUriServ/LexUriServ.do?uri= COM:2006:0399:FIN:EN:PDF, 15.04.2015.

European Commission (2011), Proposal for a Council Directive on a common system of financial transaction tax amending Directive 2008/7/EC, COM(2011) 594 final, Brussels, 28.09.2011, $\mathrm{http} / / / \mathrm{ec}$. europa.eu/taxation_customs/resources/documents/taxation/other_taxes/financial_sector/com\%282011\%29594_en.pdf, 15.04.2015.

European Commission (2012), Proposal for a Council decision authorising enhanced cooperation in the area of financial transaction tax, $\operatorname{COM(2012)~} 631$ final/2, http://ec.europa.eu/taxation_customs/resources/documents/taxation/com_2012_631_en.pdf, 15.05.2015. 
Fiorini A. (2010), Harmonizing the Law Applicable to Divorce and Legal Separation - En hanced Cooperation as a Way Forward?, „International \& Comparative Law Quarterly”, vol. 59, issue 4.

Grahl J., Lysandrou P. (2014), The European Commission's Proposal for a Financial Transactions Tax: A Critical Assessment, „Journal of Common Market Studies”, vol. 52, nr 2.

Hübner D. (2003), Przesilenie przed dobrym finatem. Rozmowa z Danutą Hübner, „Tygodnik Powszechny", nr 25 (2814), z 22.06.2003.

Komisja Europejska (2011), Wniosek: Rozporzadzenie Parlamentu Europejskiego i Rady wprowadzajace wzmocnionq wspótprace $w$ dziedzinie tworzenia jednolitego systemu ochrony patentowej, Bruksela, 13.4.2011, KOM(2011) 215 wersja ostateczna, http://eurlex.europa.eu/LexUriServ/LexUriServ.do?uri=COM:2011:0215:FIN:PL:PDF, 16.05.2015.

Komisja Europejska (2013), Wniosek: Dyrektywa Rady w sprawie wdrożenia wzmocnionej wspólpracy w dziedzinie podatku od transakcji finansowych, $\operatorname{COM(2013)~} 71$ final, Bruksela, 14.02.2013, $\mathrm{http} / / /$ eur-lex.europa.eu/legal-content/PL/TXT/PDF/?uri=CELEX:52013PC0071\&from=EN, 20.05 .2015 .

Komitet Ekonomiczno-Społeczny (2012), Opinia Europejskiego Komitetu Ekonomiczno-Spotecznego w sprawie wniosku dotyczacego dyrektywy Rady w sprawie wspólnego systemu podatku od transakcji finansowych i zmieniajacej dyrektywę 2008/7/WE, COM(2011) 594 final, Dz. Urz. UE, C 181, 21.06.2012.

Komitet Regionów (2012), Opinia Komitetu Regionów ,, Wspólny system podatku od transakcji finansowych", Dz. Urz. UE, C 113, 18.04.2012.

Konwencja pomiędzy Królestwem Belgii, Republika Federalnq Niemiec, Królestwem Hiszpanii, Republika Francuska, Wielkim Księstwem Luksemburga, Królestwem Niderlandów i Republika Austrii w sprawie intensywniejszej wspólpracy transgranicznej, szczególnie w walce z terroryzmem, przestępczościa transgraniczna i nielegalnq migracja, Rada Unii Europejskiej. Bruksela, 6 grudnia 2006 r. (18.01), 16382/06, http://register.consilium.europa.eu/pdf/pl/ 06/st16/st16382.p106.pdf, 5.05.2015.

Konwencja wiedeńska o prawie traktatów, sporzqdzona w Wiedniu dnia 23 maja 1969 r., Dz. U. 1990. $\mathrm{Nr} 74$, poz. 439.

Kubin T. (2006), Zdynamizowanie procesu integracji czy członkostwo różnych kategoriì? Zagadnienie wzmocnionej wspólpracy w Unii Europejskiej, w: Unia Europejska i Polska wobec dylematów integracyjnych na poczatku XXI wieku, red. M. Stolarczyk, Wydawnictwo Adam Marszalek, Toruń.

Kubin T. (2010), Wzmocniona wspótpraca państw Unii Europejskiej w świetle Traktatu z Lizbony. „Rocznik Integracji Europejskiej”, nr 4.

Kubin T. (2012), Kryzys gospodarczy i zadlużeniowy a zróżnicowanie integracji w Unii Europejskiej, „Studia Europejskie”, nr 3 (63).

Kuipers J.-J. (2012), The Law Applicable to Divorce as Test Ground for Enhanced Cooperation, „European Law Journal", vol. 18, nr 2.

Luxembourg European Council. Presidency Conclusions, 12.12.1997, http://www.consilium.europa.eu/uedocs/cms_data/docs/pressdata/en/ec/032a0008.htm, 20.05.2015.

Oświadczenie ze szczytu państw strefy euro, Bruksela, 26 października $2011 \mathrm{r}$., http://www.consilium.europa.eu/uedocs/cms_data/docs/pressdata/PL/ec/125655.pdf, 20.05.2015.

Pakt euro plus. Ściślejsza koordynacja polityki gospodarczej służqca zwiększeniu konkurencyjności i konwergencji, Rada Europejska 24-25 marca 2011 roku, Konkluzje, Załącznik I, http://www.consilium.europa.eu/uedocs/cms_data/docs/pressdata/PL/ec/120311.pdf, 19.05.2015.

Parlament Europejski (2010), Rezolucja legislacyjna Parlamentu Europejskiego z dnia 16 czerwca 2010 r. w sprawie projektu decyzji Rady upoważniajacej do podjęcia wzmocnionej wspólpra- 
cyw dziedzinie prawa właściwego dla rozwodów i separacji (09898/2/2010-C7-0145/2010 - 2010/0066(NLE)), http://www.europarl.europa.eu/sides/getDoc.do?type=TA\&reference= P7-TA-2010-0216\& format $=$ XML\&language $=$ PL, 18.05.2015.

Parlament Europejski (2012a), Rezolucja ustawodawcza Parlamentu Europejskiego z dnia 23 maja 2012 r. w sprawie wniosku dotyczacego dyrehtywy Rady w sprawie wspólnego systemu podat$k u$ od transakcji finansowych $i$ zmieniajacej dyrektywe 2008/7/WE (COM(2011)0594 - C7-0355/2011 - 2011/0261(CNS)), http://www.europarl.europa.eu/sides/getDoc.do?pubRef $=-/ /$ EP//TEXT + TA + P7-TA-2012-0217+0+DOC + XML + V0//PL, 21.05.2015.

Parlament Europejski (2012b), Rezolucja ustawodawcza Parlamentu Europejskiego z dnia 12 grudnia 2012 r. w sprawie wniosku dotyczacego decyzji Rady upowazniającej do podjęcia wzmocnionej wspólpracy $w$ dziedzinie podatku od transakcji finansowych (COM(2012)0631 - C7-0396/2012 - 2012/0298(APP)), http://www.europarl.europa.eu/sides/getDoc.do?pu$\mathrm{bRef}=-/ / \mathrm{EP} / / \mathrm{TEXT}+\mathrm{TA}+\mathrm{P} 7-\mathrm{TA}-2012-0498+0+\mathrm{DOC}+\mathrm{XML}+\mathrm{V} 0 / / \mathrm{PL}, 23.05 .2015$.

Parlament Europejski (2013), Rezolucja ustawodawcza Parlamentu Europejskiego z dnia 3 lipca $2013 \mathrm{r}$. w sprawie wniosku dotyczqcego dyrektywy Rady w sprawie wdrożenia wzmocnionej wspólpracy w dziedzinie podatku od transakcji finansowych (COM(2013)0071-C7-0049/2013 - 2013/0045(CNS)), http://www.europarl.europa.eu/sides/getDoc.do?pubRef=-//EP//TEXT+ $\mathrm{TA}+\mathrm{P} 7-\mathrm{TA}-2013-0312+0+\mathrm{DOC}+\mathrm{XML}+\mathrm{V} 0 / / \mathrm{PL}, 23.05 .2015$.

Peers S. (2010), Divorce, European Style: The First Authorization of Enhanced Cooperation, „European Constitutional Law Review", vol. 6, Issue 3.

Podstawowe ustalenia w sprawie Europejskiego Mechanizmu Stabilności, Rada Europejska 24-25 marca 2011 roku, Konkluzje, Załącznik II, http:/www.consilium.europa.eu/uedocs/ cms_data/docs/pressdata/PL/ec/120311.pdf, 15.05.2015.

Porozumienie w sprawie Jednolitego Sadu Patentowego, Dz. Urz. UE, C 175, 20.06.2013.

Protocol integrating the Schengen acquis into the framework of the European Union, Treaty of Amsterdam amending the Treaty on European Union, the Treaties establishing the European Communities and related acts, O.J., C 340, 10.11.1997.

Protocol on the acquisition of property in Denmark, Treaty on European Union, O.J., C 191. 29.07.1992.

Protocol on certain provisions relating to the United Kingdom of Great Britain and Northern Ireland. Treaty on European Union, O.J., C 191, 29.07.1992.

Protocol on certain provisions relating to Denmark, Treaty on European Union, O.J., C 191. 29.07 .1992 .

Protocol on social policy, Treaty on European Union, O.J., C 191, 29.07.1992.

Protocol on the application of certain aspects of Article 7 a of the Treaty establishing the European Community to the United Kingdom and to Ireland, Treaty of Amsterdam amending the Treaty on European Union, the Treaties establishing the European Communities and related acts. O.J., C 340, 10.11.1997.

Protocol on the position of the United Kingdom and Ireland, Treaty of Amsterdam amending the Treaty on European Union, the Treaties establishing the European Communities and related acts. O.J., C 340, 10.11.1997.

Protocol on the position of Denmark, Treaty of Amsterdam amending the Treaty on European Union, the Treaties establishing the European Communities and related acts, O.J., C 340. 10.11.1997.

Protokót w sprawie dorobku Schengen właczonego w ramy Unii Europejskiej, Traktat z Lizbony zmieniajacy Traktat o Unii Europejskiej i Traktat ustanawiajacy Wspólnotę Europejska, Dz. Urz. UE, C 306, 17.12.2007. 
Protokót w sprawie eurogrupy, Traktat z Lizbony zmieniajacy Traktat o Unii Europejskiej i Traktat ustanawiajacy Wspólnotę Europejska, Dz. Urz. UE, C 306, 17.12.2007.

Protokól w sprawie stalej wspólpracy strukturalnej ustanowionej na mocy artykulu 42 Traktatu o Unii Europejskiej, Wersja skonsolidowana Traktatu o Unï Europejskiej, Dz. Urz. UE, C 83, 30.03.2010.

Protokól w sprawie stanowiska Danii, Traktat z Lizbony zmieniajacy Traktat o Unii Europejskiej i Traktat ustanawiajacy Wspólnotę Europejska, Dz. Urz. UE, C 306, 17.12.2007.

Protokót $w$ sprawie stanowiska Zjednoczonego Królestwa i Irlandii w odniesieniu do przestrzeni wolności, bezpieczeństwa i sprawiedliwości, Traktat z Lizbony zmieniajacy Traktato Unii Europejskiej i Traktat ustanawiający Wspólnotę Europejska, Dz. Urz. UE, C 306, 17.12.2007.

Protokót w sprawie stosowania Karty Praw Podstawowych Unii Europejskiej do Polski i Zjednoczonego Królestwa, Traktat z Lizbony zmieniajacy Traktat o Unii Europejskiej i Traktat ustanawiajacy Wspólnotę Europejska, Dz. Urz. UE, C 306, 17.12.2007.

Rada Europejska (2012), Rada Europejska z 28/29 czerwca 2012 r., konkluzje, EUCO 76/12. Załącznik: „Pakt na rzecz wzrostu gospodarczego i zatrudnienia”, s. 13, http://data.consilium.europa.eu/doc/document/ST-76-2012-INIT/pl/pdf, 21.05.2015.

Rada UE (2012), 3178 posiedzenie Rady Unii Europejskiej, Luksemburg, 22 czerwca 2012 r.. 11598/12, http:/data.consilium.europa.eu/doc/document/ST-11598-2012-INIT/pl/pdf, 21.05.2015.

Rada UE (2014), 3310. Posiedzenie Rady Unii Europejskiej (Sprawy Gospodarcze i Finansowe). 6 maja 2014, 9375/14, http://data.consilium.europa.eu/doc/document/ST-9375-2014-INIT/ $\mathrm{pl} / \mathrm{pdf}, 22.05 .2015$.

Rozporządzenie Parlamentu Europejskiego i Rady (UE) nr 1173/2011z dnia 16 listopada 2011 r. w sprawie skutecznego egzekwowania nadzoru budżetowego w strefie euro, Dz. Urz. UE, L 306, 23.11.2011.

Rozporządzenie Parlamentu Europejskiego i Rady (UE) nr 1174/2011z dnia 16 listopada 2011 r. w sprawie środków egzekwowania korekty nadmiernych zaktóceń równowagi makroekonomicznej w strefie euro, Dz. Urz. UE, L 306, 23.11.2011.

Rozporządzenie Parlamentu Europejskiego i Rady (UE) nr 1175/2011z dnia 16 listopada 2011 r. zmieniajace rozporzadzenie Rady (WE) nr 1466/97 w sprawie wzmocnienia nadzoru pozycji budżetowych oraz nadzoru i koordynacji polityk budżetowych, Dz. Urz. UE, L 306, 23.11.2011.

Rozporządzenie Parlamentu Europejskiego i Rady (UE) nr 1176/2011z dnia 16 listopada 2011 r. w sprawie zapobiegania zakłóceniom równowagi makroekonomicznej i ich korygowania. Dz. Urz. UE, L 306, 23.11.2011.

Rozporządzenie Parlamentu Europejskiego i Rady (UE) nr 1177/2011z dnia 16 listopada 2011 r. w sprawie przyspieszenia i wyjaśnienia procedury nadmiernego deficytu, Dz. Urz. UE, L 306, 23.11.2011.

Rozporządzenie Parlamentu Europejskiego i Rady (UE) nr 1257/2012 z dnia 17 grudnia 2012 r. wprowadzajace wzmocnionq wspótpracę $w$ dziedzinie tworzenia jednolitego systemu ochrony patentowej, Dz. Urz. UE, L 361, 31.12.2012.

Rozporządzenie Rady (UE) nr 1260/2012 z dnia 17 grudnia 2012 r. wprowadzajacej wzmocniona wspólpracę $w$ dziedzinie tworzenia jednolitego systemu ochrony patentowej w odniesieniu do majacych zastosowanie ustaleń dotyczacych thumaczeń, Dz. Urz. UE, L 361, 31.12.2012.

Sprawy połączone C-274/11 i C-295/11, Królestwo Hiszpanii i Republika Włoska przeciwko Radzie Unii Europejskiej, ECLI:EU:C:2013:240.

Sprawa C-209/13, Zjednoczone Królestwo Wielkiej Brytanii i Irlandii Pólnocnej przeciwko Radzie Unii Europejskiej. Wspólny system podatku od transakcji finansowych - Upoważnienie do wzmocnionej wspótpracy na podstawie art. 329 ust. I TFUE - Decyzja 2013/52/UE - Skarga o stwierdzenie nieważności w zwiqzku z naruszeniem art. 327 TFUE, art. 332 TFUE oraz międzynarodowego prawa zwyczajowego, ECLI:EU:C:2014:283. 
Tobin J. (1974), The new economics one decade older, Princeton University Press, Princeton.

Tobin J. (1978), A proposal for international monetary reform, „Eastern Economic Journal”, vol. 4, nr 3-4.

Treaty of Amsterdam amending the Treaty on European Union, the Treaties establishing the European Communities and related acts, O.J., C 340, 10.11.1997.

Treaty of Nice amending the Treaty on European Union, the Treaties establishing the European Communities and certain related acts, O.J., C 80, 10.3.2001.

Treaty on European Union, O.J., C 191, 29.07.1992.

Traktat o stabilności, koordynacji i zarzadzaniu w Unii Gospodarczej i Walutowej, http://european-council.europa.eu/media/639256/16 - tscg.pl.12.pdf, 19.03.2012.

Traktat z Lizbony zmieniajacy Traktat o Unii Europejskiej i Traktat ustanawiajacy Wspólnotę Europejskq, Dz. Urz. UE, C 306, 17.12.2007.

Traktat ustanawiający Europejska Wspólnotę Gospodarcza (1957), „Zbiór Dokumentów”, nr 5.

Wersja skonsolidowana Traktatu o funkcjonowaniu Unii Europejskiej, Dz. Urz. UE, C 83, 30.03.2010.

Wersja skonsolidowana Traktatu o Unii Europejskiej, Dz. Urz. UE, C 83, 30.3.2010.

\section{Streszczenie}

Przez ponad dekadę postanowienia o możliwości ustanowienia w Unii Europejskiej wzmocnionej współpracy (wprowadzone na mocy Traktatu z Amsterdamu) nie były wykorzystywane. Po raz pierwszy stało się to w 2010 r. Od tego momentu Rada UE jeszcze dwukrotnie podejmowała decyzje o ustanowieniu takiej współpracy - ostatnio w 2013 r. w sprawie podatku od transakcji finansowych (PTF; ang. financial transaction tax). W ten sposób wzmocniona współpraca staje się trwałą i coraz ważniejszą formą współpracy w UE, przyczyniając się do pogłębienia zróżnicowania integracji w Unii.

Celem artykułu jest przedstawienie znaczenia rozwoju wzmocnionej współpracy, w tym przede wszystkim kolejnej decyzji o jej ustanowieniu w zakresie PTF, dla funkcjonowania UE. Aby zarysować kontekstu tego problemu, syntetycznie wskazano także zawarte w traktatach podstawy prawne wzmocnionej współpracy, przejawy zróżnicowania integracji sprzed roku 2010, wymieniono działania i decyzje podjęte przez państwa i instytucje UE w związku z kryzysem gospodarczym, które również wpłynęły na zróżnicowanie integracji w UE oraz krótko przybliżono dwa pierwsze przypadki ustanowienia wzmocnionej współpracy. Najistotniejsze wnioski zawarto w ostatniej części artykułu.

Slowa kluczowe: wzmocniona współpraca, podatek od transakcji finansowych, zróżnicowanie integracji w Unii Europejskiej

\section{Enhanced cooperation in the European Union for the third time.} The progressing diversity of integration, and the development of enhanced cooperation and its importance for the functioning of the $\mathbf{E U}$

\section{Summary}

The Treaty of Amsterdam introduced the provisions concerning the establishment of enhanced cooperation in the European Union that were not been applied for over a decade after its 
signing. The first time it happened was in 2010 . The EU Council made a decision to establish such a form of cooperation on two more occasions - most recently in 2013, on a financial transaction tax (FTT). In this way, the enhanced cooperation has become a permanent and increasingly important form of cooperation within the EU, helping to deepen the diversity of integration in the Union.

The paper aims to show the importance of the development of enhanced cooperation, including in particular the subsequent decision to implement enhanced cooperation in the area of FTT, for the functioning of the EU. To outline the context of this problem, the legal basis for enhanced cooperation contained in the Treaties and the examples of integration diversity before 2010 are synthetically indicated; the actions and decisions taken by the states and the EU institutions in connection with the economic crisis, which also affected the diversity of integration in the EU, are listed; and the two first cases of enhanced cooperation are briefly described. The most important conclusions are contained in the final part of the study.

Key words: enhanced cooperation, financial transaction tax, differentiation of integration in the EU 
